\title{
Zatrudnianie członków zarządu w spółce kapitałowej na podstawie umowy o pracę
}

\section{Uwagi wstępne}

Zagadnienie przedstawione w niniejszym opracowaniu ma charakter złożony i od wielu lat budzi wątpliwości zarówno w doktrynie, jak i w orzecznictwie. Problemy praktyczne związane z zatrudnieniem członków zarządu w spółce kapitałowej wynikają z konieczności stosowania regulacji należących do odrębnych gałęzi prawa oraz niedostatecznego unormowania relacji między spółką a członkami jej organów². Warto zauważyć, iż wykorzystanie umowy o pracę, jako podstawy wiążącej strony więzi prawnej może prowadzić do kolizji pomiędzy charakterystyczną dla prawa pracy zasadą ochrony trwałości stosunku pracy a zasadami prowadzenia działalności gospodarczej i swobodą obsadzania stanowisk w zarządach spółek kapitałowych ${ }^{3}$.

\section{Wymagania wobec członka zarządu spółki kapitałowej}

Specyfika zatrudnienia członka zarządu spółki kapitałowej wyraża się w konieczności spełnienia ustawowych wymogów określonych w art. 18 kodeksu spółek handlowych (dalej k.s.h.) ${ }^{4}$. Zgodnie z uregulowaniem członkiem zarządu może być tylko osoba fizyczna mająca pełną zdolność do czynności prawnych. Tym samym członkiem zarządu nie może zostać osoba fizyczna, która nie uzyskała pełnoletniości, osoba prawna ani jednostka organizacyjna nie posiadająca osobowości prawnej, której ustawa przyznaje zdolność prawną.

Poza tym, zgodnie z powołanym wyżej przepisem, członkiem zarządu nie może zostać osoba skazana prawomocnym wyrokiem za przestępstwa określone w przepisach rozdziałów XXXIII-XXXVII kodeksu karnego ${ }^{5}$ (dalej: k.k.) oraz w art. 585, 587, 590 i 591 k.sh.. Zakaz ustaje $\mathrm{z}$ upływem piątego roku od dnia uprawomocnienia się wyroku

\footnotetext{
${ }^{1}$ Absolwent, Uniwersytet Łódzki, Wydział Prawa i Administracji.

${ }^{2}$ A. Giedrewicz, Wybór jako podstawa nawiq̨zania stosunku pracy z członkami zarzadu spółek kapitałowych, „Monitor Prawniczy” nr 14/2004, s.641 i nast.

3 Uchwała Sądu Najwyższego z dnia 16 maja 2012 r., III PZP 3/12, OSNAPiUS 2012 nr 23-24, poz. 279, s. 968.

${ }^{4}$ Ustawa z dnia 15 września 2000 r. Kodeks spółek handlowych, Dz.U. 2000, nr 94, poz. 1037.

5 Ustawa z dnia 6 czerwca 1997 r. Kodeks karny, Dz.U. 1997, nr 88, poz. 553.
} 
skazującego, jednakże nie może zakończyć się wcześniej niż z upływem trzech lat od dnia zakończenia okresu odbywania kary. $\mathrm{W}$ terminie trzech miesięcy od dnia uprawomocnienia się wyroku skazany może złożyć wniosek do sądu, który wydał wyrok, o zwolnienie go z zakazu pełnienia funkcji w spółce handlowej lub o skrócenie czasu obowiązywania zakazu. Nie dotyczy to przestępstw popełnionych umyślnie. Sąd rozstrzyga o wniosku, wydając postanowienie.

Należy zauważyć, iż nie są to jedyne ograniczenia podmiotowe występujące $\mathrm{w}$ polskim porządku prawnym. Warto wspomnieć na przykład o art. $41 \S 1$ k.k., który stanowi, iż sąd może orzec zakaz zajmowania określonego stanowiska albo wykonywania określonego zawodu, jeżeli sprawca nadużył przy popełnieniu przestępstwa stanowiska lub wykonywanego zawodu, albo okazał, że dalsze zajmowanie stanowiska lub wykonywanie zawodu zagraża istotnym dobrom chronionym prawem. Poza tym, przepisy ustawy o ograniczeniu prowadzenia działalności gospodarczej przez osoby pełniące funkcje publiczne nakładają zakaz sprawowania między innymi funkcji członka zarządu $\mathrm{w}$ okresie pełnienia funkcji publicznych przez enumeratywnie określone kategorie podmiotów ${ }^{6}$.

Co więcej, umowa spółki z ograniczoną odpowiedzialnością lub statut spółki akcyjnej mogą rozszerzać wymogi stawiane kandydatom na członka zarządu w postępowaniu kwalifikacyjnym. Specyfika pełnienia funkcji, związana przede wszystkim z ponoszeniem surowej odpowiedzialności, wymaga, aby kandydat na stanowisko posiadał określone kompetencje i kwalifikacje. W praktyce najczęściej można spotkać się z wymogami takimi jak: ukończenie studiów wyższych, odpowiedni staż pracy na stanowisku kierowniczym, umiejętność analitycznego myślenia, znajomość języków obcych.

\section{Stosunek członkostwa w zarządzie a stosunek zatrudnienia}

W wyniku powołania pomiędzy spółką a członkiem zarządu powstaje stosunek organizacyjny. Może być to wyłączna podstawa pełnienia funkcji w zarządzie spółki kapitałowej. Powołanie na funkcję członka zarządu nie rozstrzyga kwestii wynagrodzenia za świadczone usługi. Dopóki nie zostanie w tym przedmiocie podjęta szczegółowa uchwała, członek zarządu nie otrzymuje żadnego ekwiwalentu za

\footnotetext{
6 Ustawa z dnia 21 sierpnia 1997 r. o ograniczeniu prowadzenia działalności gospodarczej przez osoby pełniące funkcje publiczne, Dz.U. 1997, nr 106, poz. 679.
} 
świadczenie usług na rzecz spółki . Dlatego też dopuszczalne jest nawiązanie dodatkowego stosunku zobowiązaniowego cechującego się odrębnością i niezależnością od więzi korporacyjnej.

Należy zauważyć, iż k.s.h. nie wskazuje bezpośrednio możliwych podstaw zatrudnienia członków zarządu. Art. $203 \S 1$ i art. 370 $\S 1$ k.s.h. stanowią natomiast, że odwołanie członka zarządu nie pozbawia go roszczeń ze stosunku pracy lub innego stosunku prawnego dotyczącego pełnienia funkcji członka zarządu. Co więcej, art. 378 § 1 k.s.h. określa, iż rada nadzorcza spółki akcyjnej ustala wynagrodzenie członków zarządu zatrudnionych na podstawie umowy o pracę lub innej umowy, chyba że statut stanowi inaczej. Analiza powołanych przepisów prowadzi do wniosku, iż z członkiem zarządu może zostać nawiązany zarówno stosunek pracy, jak i umowa cywilnoprawna, np.: umowa o zarządzenie spółką albo umowa o świadczenie usług.

\section{Zatrudnienie członka zarządu w reżimie pracowniczym}

Zatrudnienie członka zarządu w reżimie pracowniczym ma charakter atypowy. Jego wykorzystanie budzi wątpliwości ze względu na występujące $\mathrm{w}$ ramach stosunku pracy podporządkowanie pracownika oraz obowiązek starannego działania. Przywołane cechy pozostają w sprzeczności z oceną prowadzenia spraw spółki przez osoby zarządzając pod względem osiągniętego wyniku ekonomicznego, a także możliwym ponoszeniem przez nich surowej odpowiedzialności określonej w przepisach k.s.h. Warto zauważyć, iż członkowie zarządu objęci są ex lege zakazem konkurencji wynikającym z art. 211 i 388 k.s.h., który może zostać doprecyzowany w odrębnej umowie.

Z członkiem zarządu nie może zostać nawiązany stosunek pracy na wszystkich podstawach wymienionych $\mathrm{w}$ art. 2 kodeksu pracy ${ }^{8}$ (dalej: k.p.). W szczególności nie jest możliwe zatrudnienie członka zarządu na podstawie mianowania, powołania oraz spółdzielczej umowy o pracę. W dwóch pierwszych przypadkach brak ku temu odpowiedniej podstawy prawnej. Spółdzielcza umowa o pracę jest natomiast stosowana jedynie $w$ relacji pomiędzy spółdzielnią pracy a jej członkami. Dlatego też jedynymi dopuszczalnymi podstawami pracowniczego zatrudnienia członka zarządu są: umowa o pracę oraz akt wyboru.

\footnotetext{
${ }^{7}$ R. Szczęsny, Zarzq̨d w spółkach kapitałowych, Zakamycze 2004, s.70.

8 Ustawa z dnia 26 czerwca 1974 r. Kodeks pracy, Dz.U. 1974, nr 24, poz. 141.
} 


\section{Zatrudnienie członka zarządu na podstawie umowy o pracę}

Specyfika sprawowania funkcji członka zarządu wymaga, by nawiązana więź o charakterze zobowiązaniowym była zgodna $\mathrm{z}$ istotą stosunku korporacyjnego łączącego go ze spółką. Z tego względu krytycznie należy ocenić zatrudnianie członków zarządów spółek kapitałowych na podstawie umowy o pracę.

Stronami umowy o pracę są spółka kapitałowa oraz członek zarządu. Spółkę w umowie z członkiem zarządu reprezentuje rada nadzorcza albo pełnomocnik powołany uchwałą zgromadzenia wspólników (art. $210 \S 1$ k.s.h) albo uchwałą walnego zgromadzenia (art. 379 $\S 1$ k.s.h.). W przypadku braku należytej reprezentacji umowa o pracę będzie dotknięta wadą bezwzględnej nieważności ${ }^{9}$.

W jednym z orzeczeń Sąd Najwyższy zauważył, iż „pracownik zatrudniony w charakterze członka zarządu spółki, z chwilą jego odwołania z tego zarządu, traci możliwość wykonywania swojej podstawowej powinności pracowniczej (świadczenia pracy) ${ }^{10}$. Mimo to ustanie stosunku organizacyjnego nie ma wpływu na byt umowy o pracę, która musi ulec odrębnemu rozwiązaniu.

Konieczność stosowania ochronnych przepisów k.p. dotyczących powszechnej i szczególnej ochrony przed wypowiedzeniem może doprowadzić do trudności z rozwiązaniem stosunku pracy odwołanego członka zarządu. Stabilizacja zatrudnienia gwarantowana poprzez ochronę zatrudnienia nie odpowiada specyfice spółek handlowych oraz istocie pełnienia funkcji członka zarządu. W sytuacji, gdy stosunek organizacyjny łączący członka zarządu ze spółką uległ rozwiązaniu, z punktu widzenia ekonomicznego bezzasadne wydają się zakazy wypowiedzenia umów o pracę przewidziane w k.p.. Mimo to odwołani członkowie zarządu korzystają z ochrony związanej z okresem przedemerytalnym (art. 39 k.p.), okresem ciąży i urlopu macierzyńskiego (art. 177 k.p.), czy też okresem urlopu lub innej usprawiedliwionej nieobecności (art. 41 k.p.). Nie ma też żadnych podstaw, by wyłączyć wymóg konsultacji związkowej w przypadku wypowiedzenia umowy o pracę na czas nieokreślony.

Mając na uwadze charakter świadczonej pracy oraz fakt, iż powołanie na funkcję następuje na kadencję, należy zauważyć, iż nie wszystkie rodzaje umów o pracę powinny mieć zastosowanie w przy-

\footnotetext{
9 Wyrok Sądu Najwyższego z dnia 23 stycznia 1998 r., I PKN 489/97, OSNP 1999, nr 1, poz. 8.

10 Wyrok Sądu Najwyższego z dnia 26 stycznia 2000 r. I PKN 479/99, „Monitor Prawniczy" 2001/14/746.
} 
padku zatrudnienia członka zarządu spółki kapitałowej. Poniżej zostaną przedstawione poszczególne rodzaje umów opracę wraz z komentarzem dotyczącym ewentualnych problemów praktycznych związanych z wyborem danej umowy.

Charakter prawny umowy o pracę na okres próbny pozostaje w sprzeczności z generalną zasadą prawa spółek, iż członek zarządu powoływany jest na określoną kadencję, która nie ma charakteru próbnego. W orzecznictwie Sądu Najwyższego podkreśla się, iż „umowa na okres próbny ma sprawdzać przygotowanie pracownika do wykonywania pracy określonego rodzaju"11. Należy zauważyć, że od kandydatów na członków zarządu wymaga się odpowiednich kwalifikacji i doświadczenia, najczęściej sprawdzanych w ramach postępowania kwalifikacyjnego na stanowisko. Powołanie na członka zarządu przyznaje danej osobie mandat, który jest uprawnieniem do wykonywania określonych praw i pełnienia obowiązków. W praktyce nie występuje warunkowe powołanie, które kłóciłoby się z charakterem obowiązków członka zarządu. Efekty jego pracy z punktu widzenia ekonomicznego są bowiem widoczne dopiero po upływie dłuższego okresu czasu. Pozostaje to w sprzeczności z maksymalną trzymiesięczną długością zatrudnienia na podstawie umowy o pracę na okres próbny (art. $25 \S 2$ k.p.). W związku z tym jej wykorzystanie należy uznać za odbiegające od istoty pełnienia funkcji członka zarządu.

W doktrynie i orzecznictwie podkreśla się, że możliwe jest zawarcie umowy o pracę na czas nieokreślony z członkiem zarządu spółki kapitałowej. Należy zauważyć, iż teoretycznie istnieje możliwość powołania członka zarządu spółki kapitałowej na czas nieoznaczony. W takim przypadku zgodnie z poglądem wyrażonym przez Sąd Najwyższy „,złonek zarządu (...) będzie pełnić swoją funkcję dopóty, dopóki nie spełni się którakolwiek z przesłanek wygaśnięcia mandatu (...), w szczególności zaś dopóki nie zostanie uchwałą wspólników odwołany"12. Ponadto, Sąd Najwyższy w swoim orzecznictwie podkreśla, iż „kadencyjność organów spółki prawa handlowego nie oznacza powinności zawierania przez spółkę z osobami pełniącymi funkcję jej organów umów o pracę na czas określony równy okresowi kadencji"13.

\footnotetext{
11 Wyrok Sądu Najwyższego z dnia 4 września 2013 r., II PK 358/12, LEX nr 1460947. 12 Wyrok Sądu Najwyższego z dnia 12 października 2011 r., II CSK 29/11, LEX nr 1043996.

13 Wyrok Sądu Najwyższego z dnia 10 sierpnia 2000 r., I PKN 758/99, OSNAPiUS 2002, nr 5, poz. 107.
} 
Mimo możliwości wyboru umowy o pracę na czas nieokreślony wydaje się, iż spółki kapitałowe nie powinny decydować się na jej wykorzystywanie. Zatrudnienie członka zarządu na tej podstawie jest niekorzystne dla spółki nie tylko ze względów finansowych. Wyróżniająca ten rodzaj umowy trwałość pozostaje w sprzeczności z możliwością odwołania członka zarządu w każdym czasie.

W szczególności warto zauważyć, iż odwołanie z funkcji członka zarządu nie wpływa na długość okresu wypowiedzenia ${ }^{14}$, ponieważ jedynym czynnikiem determinującym go jest okres zatrudnienia u danego pracodawcy (art. 36 k.p.). Wydaje się, iż w przypadku zatrudnienia członka zarządu najczęściej okres wypowiedzenia zawartej $\mathrm{z}$ nim umowy o pracę na czas nieokreślony będzie wynosił 2 tygodnie albo 1 miesiąc. W przypadku zastosowania okresu wypowiedzenia krótszego niż wymagany, umowa rozwiąże się z upływem okresu wymaganego, a pracownikowi przysługuje wynagrodzenie do czasu rozwiązania umowy (art. 49 k.p.). Tym samym, w razie odwołania z funkcji członka zarządu spółka kapitałowa po wypowiedzeniu umowy o pracę będzie zobowiązana wypłacać mu wynagrodzenie w okresie, w którym nie pełni swojej funkcji.

Problemem praktycznym jest także wskazanie przyczyny uzasadniającej wypowiedzenie umowy o pracę na czas nieokreślony, które stanowi obowiązek pracodawcy (art. 30 § 4 k.p.). Wspominany obowiązek pozostaje w sprzeczności z zasadą, iż członek zarządu spółki kapitałowej może być w każdej chwili odwołany (art. $203 \S 1$ oraz art. 370 $\S 1$ k.s.h.). Odwołanie z funkcji, w przeciwieństwie do wypowiedzenia umowy o pracę, nie wymaga żadnego uzasadnienia. Wątpliwości może budzić wskazanie, jako przyczyny uzasadniającej wypowiedzenie odwołania z funkcji członka zarządu i związanej z tym faktycznej niemożliwości dalszego wykonywania obowiązków. W doktrynie prawa pracy podkreśla się, iż od pracodawcy wymaga się podania skonkretyzowanej i zrozumiałej dla pracownika przyczyny, która pozwoli mu na podjęcie obrony przed sądem pracy ${ }^{15}$. W związku z tym pojawia się pytanie, czy były członek zarządu może domagać się wskazania motywów uzasadniających jego odwołanie, które następnie stało się przyczyną wypowiedzenia jego umowy o pracę? W tym przypadku Sąd Najwyższy podkreśla, iż „odwołanie pracownika ze stanowiska prezesa zarządu

\footnotetext{
14 T. Duraj, Atypowość stosunku pracy członków zarzadu spółek kapitałowych - wybrane problemy prawne, Warszawa 2008, [w:] Prawo pracy, Biblioteka Studenckich Poradni Prawnych, pod red. K. Stefańskiego, s. 142.

15 L. Mitrus, Komentarz do art. 30 Kodeksu pracy, [w:] A. Sobczyk (red.), Kodeks pracy. Komentarz, Warszawa 2014, s. 146-149.
} 
spółki akcyjnej stanowi przyczynę uzasadniającą wypowiedzenie mu umowy o pracę, której zawarcie wiązało się bezpośrednio z powołaniem go na to stanowisko" 16 .

Kwestią budzącą największe wątpliwości zarówno w doktrynie, jak i w orzecznictwie jest zakres roszczeń przysługujących pracownikowi w razie wypowiedzenia umowy o pracę. $\mathrm{W}$ doktrynie dominuje stanowisko, iż odwołanemu członkowi zarządu, któremu następnie wypowiedziano umowę o pracę, nie powinno przysługiwać roszczenie o uznanie wypowiedzenia za bezskuteczne czy przywrócenie do pracy, ze względu na brak faktycznej możliwości jego wykonania17. Należy zauważyć, iż sąd pracy nie jest władny do ponownego nawiązania takiego stosunku, ponieważ jedynie wspólnicy spółki (w przypadku spółki z.o.o.) lub rada nadzorcza (w przypadku spółki akcyjnej) posiadają kompetencje do podjęcia stosownej uchwały powołującej daną osobę na członka zarządu. Przywrócenie do pracy odwołanego członka zarządu mogłoby być uzasadnione w przypadku, gdy przed powołaniem na funkcję pomiędzy daną osobą a spółką istniał stosunek pracy, a późniejsze powstanie dodatkowej więzi korporacyjnej wpłynęło jedynie na zakres obowiązków pracowniczych.

W związku z rozbieżnością występującą w orzecznictwie Sąd Najwyższy w 2012 roku podjął uchwałę 18 , w której przyjął, iż „sąd pracy w przypadku byłego członka zarządu spółki - podlegającego szczególnej ochronie trwałości stosunku pracy - jest związany żądaniem przywrócenia do pracy wtedy, kiedy z ustaleń faktycznych wynika, że odwołanie z zarządu nastąpiło na skutek okoliczności niezwiązanych z zawinionym, nienależytym wywiązywaniem się przez niego z obowiązków organizacyjnych i zarazem pracowniczych". Jednocześnie Sąd Najwyższy zauważył, iż „przywrócenie do pracy odwołanego członka zarządu oznacza sankcjonowanie, a właściwie kreowanie stosunku prawnego jedynie w aspekcie formalnej więzi łączącej pracodawcę z pracownikiem, bez faktycznej możliwości realizacji obowiązków ze strony pracownika, jednakże samo istnienie stosunku pracy nie jest determinowane wykonywaniem przez pracownika treści umowy o pracę".

\footnotetext{
16 Wyrok Sądu Najwyższego z dnia 25 listopada 1997 r., I PKN 388/97, Rejent 1998/10/122.

17 S. Koczur, Roszczenia ze stosunku pracy członka zarzq̨du spółki kapitałowej, Warszawa 2005, s. 213.

18 Uchwała Sądu Najwyższego z dnia 16 maja 2012 r., III PZP 3/12, OSNAPiUS 2012 nr 23-24, poz. 279, s. 968.
} 
Dlatego też, najbardziej optymalnym rodzajem umowy o pracę w przypadku zatrudnienia członka zarządu jest umowa o pracę na czas określony. Przede wszystkim, uwzględnia ona czasowy charakter świadczonej pracy i pozwala na lepsze zharmonizowanie ze sobą momentu odwołania z funkcji członka zarządu oraz rozwiązania stosunku pracy. Do jej wad w przypadku członka zarządu należy niewątpliwie konieczność stosowania ochrony szczególnej przed wypowiedzeniem.

Kwestią problematyczną w praktyce może okazać się prawidłowe oznaczenie terminu, po upływie którego umowa o pracę na czas określony ulegnie rozwiązaniu. Wygaśnięcie mandatu członka zarządu co do zasady powinno nastąpić $\mathrm{w}$ dniu odbycia zgromadzenia wspólników (walnego zgromadzenia akcjonariuszy), w czasie którego zostanie zatwierdzone sprawozdanie finansowe za ostatni pełny rok obrotowy pełnienia funkcji (art. $202 \S 1$ oraz $\S 2$ i art. 369 § 4 k.s.h.). Precyzyjne wyznaczenie terminu odbycia zgromadzenia, czasami z kilkuletnim wyprzedzeniem, jest jednak niemożliwe. Najbardziej prawidłowym rozwiązaniem wydaje się określenie w umowie o pracę, iż zostaje ona zawarta do dnia, w którym odbędzie się zgromadzenie wspólników (walne zgromadzenie akcjonariuszy) zatwierdzające sprawozdanie finansowe za precyzyjnie wskazany rok kalendarzowy.

\section{Zakończenie}

Podsumowując, warto podkreślić, iż zatrudnienie członka zarządu na podstawie umowy o pracę jest rozwiązaniem korzystnym jedynie dla osoby świadczącej pracę na rzecz spółki. Z punktu widzenia ekonomicznego a także prawnego bardziej optymalnym rozwiązaniem jest wybór umowy cywilnoprawnej. W przypadku, gdy spółka jako pracodawca zdecyduje się na zatrudnianie członków zarządu w reżimie pracowniczym istotne jest, aby podstawą łączącego strony stosunku prawnego była umowa o pracę na czas określony. W przypadku wyboru umowy o pracę na czas nieokreślony może to narazić pracodawcę na ryzyko ponoszenia dodatkowych kosztów, co w przypadku spółki kapitałowej - zdaniem Sądu Najwyższego - pozostaje w sprzeczności $\mathrm{z}$ racjonalnością. 